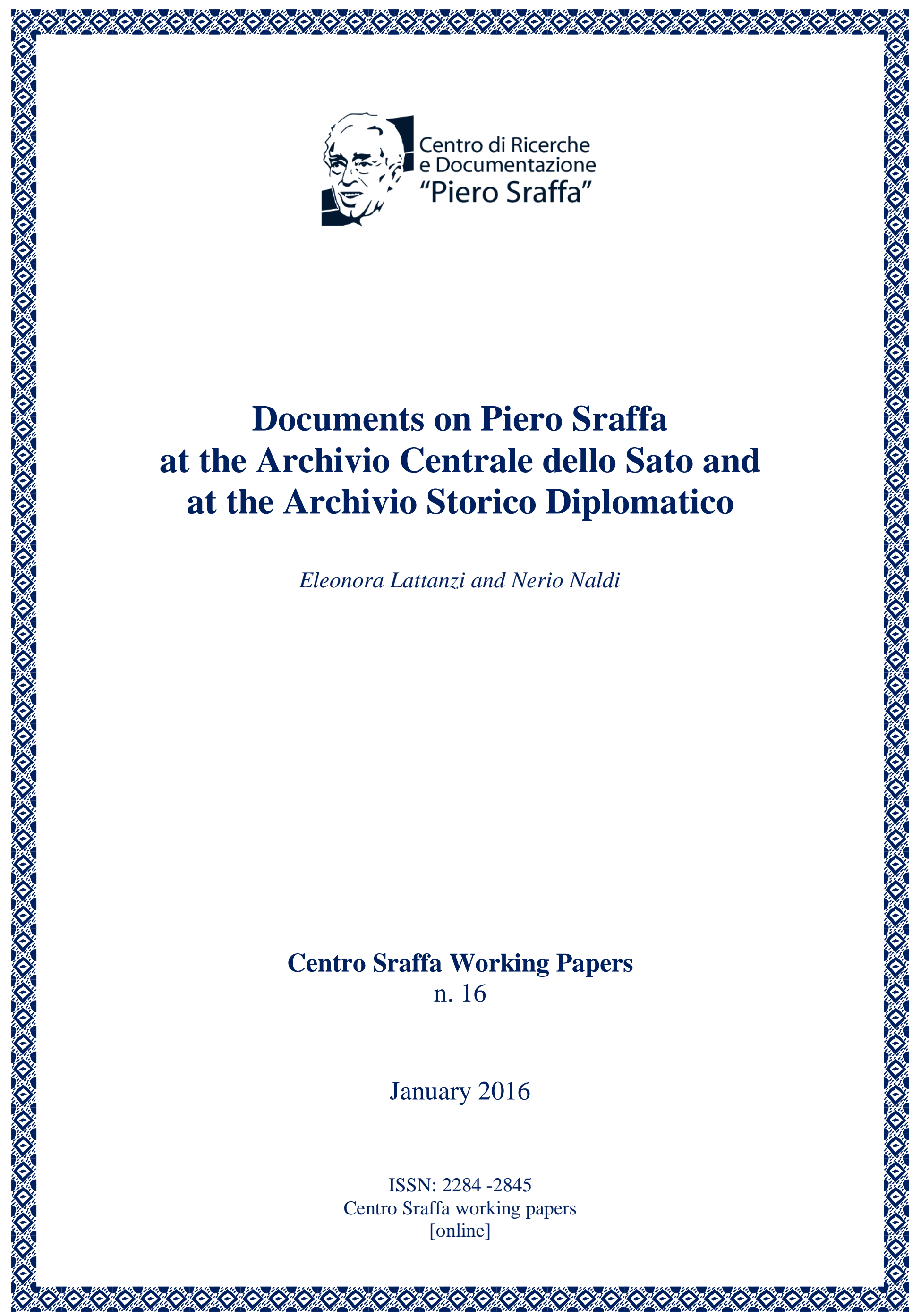




\title{
Documents on Piero Sraffa at the Archivio Centrale dello Stato and at the Archivio Storico Diplomatico
}

\author{
Eleonora Lattanzi ${ }^{\mathrm{a}} \&$ Nerio Naldi \\ ${ }^{a}$ University of Rome "La Sapienza" and Fondazione Istituto Gramsci \\ ${ }^{b}$ University of Rome "La Sapienza"
}

\begin{abstract}
This paper provides a list and a brief description of files and documents where the name of Piero Sraffa is mentioned currently kept at the Archivio Centrale dello Stato and at the Archivio Storico Diplomatico. For each file or document we provide indication of the reference number where it is conserved and a transcript of one or two of the relevant documents out of more than five hundred which have been located. The purpose of the paper is to illustrate the results of archival researches of the last decade, including more recent findings, and furnish a groundwork for further research, which may bring further light to bear on documents already known to us, and lead to the discovery of new documents or information, so as to provide a better basis to the reconstruction of the biography of Piero Sraffa and of people whose lives entwined with his - Antonio Gramsci certainly ranking high among them.

Given the nature of this work, providing precise indications as to the exact location of the documents is crucial, and this implies that any such indication must be presented in Italian. Furthermore, as almost all the documents considered were written in Italian, also providing quotations in the original language seemed to us of special importance. For these reasons, we have asked the editors of this series of working papers - usually available only in English - to allow us to present our work also in Italian.
\end{abstract}

Keywords: Sraffa, Gramsci, archives

JEL Codes: B31

\section{Introduction $^{1}$}

This paper provides a list and a brief description of files and documents where the name of Piero Sraffa is mentioned currently kept at the Archivio Centrale dello

\footnotetext{
1 The authors (joint editors of the correspondence between Piero Sraffa and Tatiana Schucht forthcoming within the Edizione nazionale degli scritti di Antonio Gramsci) wish to thank, with no further implications, Franco Aqueci, Leonardo Pompeo D’Alessandro, Giancarlo de Vivo, Barbara Gessa and Chiara Pisu (University of Cagliari), Andrea Ginzburg, Helmut Goetz, Claudio Mancini, Gerardo Padulo, Luigi Pasinetti, Alessandro Roncaglia, Maria Luisa Righi, Stefania Ruggeri, Graham Sells, Jonathan Smith, the staff of Archivio Centrale dello Stato and Archivio Storico Diplomatico del Ministero degli Affari Esteri, all the archival institutions mentioned in the paper, and an anonymous referee. Sections 1-5 and 8-11 were written by Nerio Naldi; Sections 6-7 and 12-16 were written by Eleonora Lattanzi. Financial support from University of Rome "La Sapienza" is gratefully acknowledged.
} 
Stato (ACS) and at the Archivio Storico Diplomatico (ASD). ${ }^{2}$ For each file or document we provide indication of the reference number where it is located and a transcript of one or two of the relevant documents. The purpose of the paper is to illustrate the results of archival researches of the last decade, including more recent findings (the total number of sheets directly mentioning the name of Piero Sraffa that we have located amounts to more than five hundred), and furnish a groundwork for further research, which may bring further light to bear on documents already known to us, and lead to the discovery of new documents or information, so as to provide a better basis to the reconstruction of the biography of Piero Sraffa and of people whose lives entwined with his - Antonio Gramsci certainly ranking high among them. It must be stressed that the paper we are presenting reflects a research of an essentially archival nature and that no attempt will be made here at producing a complete reconstruction of Piero Sraffa's life history. However a brief summary of the main strands of Sraffa's biography which are highlighted by documents kept in the two archives we have studied may be a useful introduction to our work.

On the evidence of the files indicated we can follow Piero Sraffa's life history, starting from the final years of his military service (he was born in 1898 and served in the Italian army between 1916 and 1920), and we may see how he refused a military award (Section 1). Shortly afterwards, in 1922, we find the Italian police casting an eye upon him as a communist or subversive (Section 3) and, in December 1922, Mussolini himself - prime minister since less than two months - tried to induce him to retract the content of an article he had just published in the English press (Section 4). We move then to Sraffa's academic career (Sections 5-7, 11, 16): his libera docenza; his appointment in Cagliari; the leave which allowed him to move to Cambridge (here we can see how different views emerged among the Italian Ministry of Foreign Affairs, the Ministry of Internal Affairs and the Italian Embassy in London on the opportunity of granting Sraffa permission to remain abroad and to teach in England; how his uncle Mariano D'Amelio, president of the Italian Supreme Court, used his influence to allow Piero to obtain the permission he was asking; but also how such an influence would not have granted Sraffa full protection against being arrested if other considerations - and, at a point, some good luck, or inefficiency on the police side - did not prevail); his decision to resign the Italian post when professors were required to declare their allegiance to fascism; and Mussolini's decision, in 1938, not to allow the University of Cagliari to accept a donation decided by Piero Sraffa back in 1929. Finally, we may see how the list of files documenting the surveillance exerted on Piero Sraffa by the Italian political police may be completed (but we may obviously wish other documents to be traced by future research) thanks to the find of a file which contains documents collected by the Italian police from 1931 to 1959. The latter file was created in 1951, when a British source (British sources or British police appear on more than one

\footnotetext{
${ }^{2}$ ACS preserves documents originated or collected from a large number of Italian public institutions and central bodies of the Italian government. ASD preserves documents originated or collected from the Italian Ministry of Foreign Affairs. Both archives are located in Rome.
} 
occasion in the documents we have been able to trace) seems to have requested information on Piero Sraffa, which led to transfer of the documents kept in the older file into the hitherto unknown new file (Section 13). The importance of this find is obvious, but we may add that it also allows to answer the questions precipitately asked when the former file (described in Section 12) had been first located and found to be empty: «The fascist regime oversaw Sraffa, but the documentation produced by these controls either has been stolen or has never been deposited by the Ministry of Internal Affairs [...] What could the file have contained? And when was its disappearance accomplished? Under the regime or immediately after?» (Canali 2013, p. 53). Indeed, those questions amounted to insinuate (even though other documents on Piero Sraffa produced under the fascist regime were already known (Sections 8-9), and others (Sections 14-15) were surfacing) that someone had managed to get rid of embarrassing documents concerning Sraffa's activities.

\section{Archivio Centrale dello Stato}

Presidenza del Consiglio dei Ministri, Guerra Europea, Busta 178, fascicolo 19.21.5 Commissione di inchiesta sulla violazione del diritto delle genti.

Documents drawn up in the period August $1921 .^{3}$

The file contains documents regarding the final stages in the work of the Reale commissione d'Inchiesta sulle violazioni del diritto delle genti commesse dal nemico (Royal Committee of Inquiry into breaches of human rights committed by the enemy), including a letter in which the committee chairman, Lodovico Mortara, proposed to the Prime Minister that Sraffa be awarded the Croce di cavaliere nell'Ordine della Corona d'Italia (Cross of Knight of the Order of the Crown of Italy); the proposal was effectively enacted on 8 September that same year, in recognition of the services performed by Sraffa as a member of his secretariate. As in fact emerges from the volumes containing the results of the committee's activities ${ }^{4}$ and indeed from Sraffa's service record ${ }^{5}$, between January 1919 and February 1920 Sraffa had served in the secretariate of the Royal Committee of Inquiry. ${ }^{6}$ However, we learn from the certified copy now kept in Cambridge of a letter sent by Lodovico Mortara to the Prime Minister on 13 October 1921 that Sraffa had not accepted the award and that consequent upon his refusal Lodovico Mortara had asked for the award decree to be revoked. ${ }^{7}$

\footnotetext{
${ }^{3}$ The chronological intervals indicated in this and the following Sections refer only to documents relevant to Sraffa's life history, and not to the whole set of documents contained in each item.

${ }^{4}$ Relazioni della Reale commissione d'inchiesta sulle violazioni del diritto delle genti commesse dal nemico, Casa editrice d'arte Bestetti e Tumminelli, Milano-Roma, 1919-1921.

${ }_{5}^{5}$ Comando Regione Militare Nord Ovest, Stato Maggiore, Ufficio personale, Archivio; Sraffa Papers A1/2/8 (the Piero Sraffa Papers are kept in the Wren Library of Trinity College, Cambridge).

${ }^{6}$ Some clues of the activity performed by Sraffa can be found in volume VI of the Committee Reports (pp. 335-45, 361-67), from which it emerges that in the months of January and February 1919 Sraffa was engaged in collecting evidence in the provinces of Venice and Trieste.

${ }^{7}$ Sraffa Papers, Add.ms.a.153.
} 
The texts of the relevant letters from Lodovico Mortara to the Prime Minister of 6 August and 13 October 1921 read as follows:

Royal Committee of Inquiry into breaches of human rights committed by the enemy Rome, 6 August 1921

N. 1531

To HE the Prime Minister, Rome

With the publication of the last three volumes of Reports = a copy of which I am honoured to send to Your Excellency, completing the proceedings = the task assigned to the Royal Committee of Inquiry with the decree of 15 November 1918 n.1711 has been fulfilled.

I am therefore honoured to return to Your Excellency the mandate entrusted to me to chair the Committee, which is dissolved on completion of the work for which it was created, and having informed the Reparation Committee of the findings emerging from the various investigations.

In previous reports I had already mentioned the highly commendable work carried out by all the members of the R.Committee to the Prime Minister's Office, which, acting upon my proposals promoted and implemented the conferment of awards on members distinguished by particular zealousness, competence and intelligence in recording and coordinating the vast and complex material. I am, however, duty-bound to make a final proposal to Your Excellency in favour of the three secretaries who, despite their praiseworthy contribution to the successful outcome of the work with their diligent and assiduous services, have yet to receive due recognition. ${ }^{8}$

For one of them = cav. dott. Eugenio RE, former lieutenant of the Artillery and at present first secretary of the Ministry of Colonies, I had already proposed with letter no. 1168 of 22 July 1919, that he be awarded the honour of knight of the Mauritian Order, but an obstacle lay in the fact that the two-year period since his appointment as knight of the Crown of Italy was not yet over; I now renew my previous request in the hope that Your Excellency will receive it favourably.

As for the other two = Dr. Piero SRAFFA son of Angelo, former lieutenant of the Corps of Engineers, domiciled in Milan, via Ugo Foscolo n.1, and Dr. Lodovico VARCASIA, son of the late Eugenio, former second lieutenant of the Infantry, domiciled in Rome, Via Tacito n. 41 = I request Your Excellency to favour award of the Cross of Knight of the Order of the Crown of Italy.

Finally, I am honoured to inform Your Excellency that I have arranged for twenty copies of the Reports to be placed at the disposal of the Most Excellent Prime Minister. THE COMMITTEE CHAIRMAN

\section{Mortara}

\footnotetext{
${ }^{8}$ The three paragraphs that follow are joined by a bracket drawn by hand, with beside it the note: «provveduto per le onorificenze v fasc. 2231 Onorif. Presidenza» (steps taken for the awards, see folder 2231 Awards PM).
} 
Royal Committee of Inquiry into breaches of human rights committed by the enemy Rome, 13 October 19[2]1

N. 1534

His Excellency the Prime Minister, Rome

CONFIDENTIAL

Copy

Dr. Piero Sraffa, former secretary Royal Committee of Inquiry into breaches of human rights committed by the enemy, was on my request proposed by Your Excellency with others for award of a knighthood by royal motu proprio. And with a telegram dated 11 September Your Excellency was pleased to inform me of the appointment of Dr. Sraffa as knight of the Crown of Italy.

On unofficial notification of the award to Dr. Sraffa, who had for some time been living in England, he stated that, while grateful for the recognition of his services accorded him, his political opinions and ties with the republican party compelled him to decline the honour.

This unforeseen response obliges me with great regret to request Your Excellency to enter upon the appropriate procedures to revoke the royal decree of 8 September with which Dr. Pietro Sraffa was appointed knight of the Crown of Italy.

Yours faithfully

The Chairman of the Royal Committee

$\left.f^{\circ}\right)$ Mortara

By certified copy, from the Secretariat of the Royal Committee of Inquiry

Rome, 29 May 1922.

The Secretary of the Royal Committee

Claudio Matteini

\section{Archivio Centrale dello Stato}

Ministero dell'Interno, Divisione Affari Generali e Riservati, Pubblica Sicurezza, 1922, Busta 5, fascicolo Sfrafra Piero.

The file is empty.

The file's front cover bears the following classification: «Cat. Lett. $A$ N. 1 Classifica Inf» (hand-written additions are in italics). Noted on the front cover itself is registration of two documents (1922 June 22 n.17010 and 1922 August 2 n.21138), but also the fact that the documents contained have been «filed away in the Sraffa Pietro folder at $1 / 1922 »$. 


\section{Archivio Centrale dello Stato}

\section{Ministero dell'Interno, Divisione Affari Generali e Riservati, Pubblica Sicurezza, 1922, Busta 5, fascicolo Sraffa Pietro.}

Documents drawn up in the period June-July 1922.

The file, with front cover bearing the following classification: «Cat. Lett. $A$ N. 1 Classifica __ (hand-written additions are indicated in italics), contains besides the documents registered on the front cover (1922 June 22 n.17010 and 1922 August 2 $n .21138)^{9}$ draft copies of two letters dated 23 June and 21 July 1922.

These are documents that identify Piero Sraffa as a communist or subversive, apparently produced subsequent to report of his entry and illegal abode in the United Kingdom, although on the evidence we have Sraffa hardly seems likely to have entered the United Kingdom illegally, nor indeed do the timeframes deducible from the documents appear at all probable: Sraffa had spent a period of time in England from the spring of 1921 to spring of 1922, registered as research student at the London School of Economics and had returned to Italy, precisely on 3 June 1922 (Naldi 2005 pp.279-380). Nevertheless, the report remains interesting insofar as it evidences attention paid to Sraffa by the Italian police and by the British police - or by the Italian police through their informers in the United Kingdom. It may well be that the information gathered by the Italian police had to do with a journey Sraffa made from England to Ireland, quite possibly in March 1922 or thereabouts, but we lack documental evidence (Naldi 2005 pp. 380-1, 396-7) ${ }^{10}$.

Below we quote one of the annotations that open the file (we have not been able to trace back the original report) and the answer from the Prefecture of Turin dated 27 July 1922 which closes it:

\section{Express mail \\ Confidential}

Rome 23 June 922

Turin Prefect

$n .{ }^{\circ} 17010 \_$Report has come in of the presence in England, having gained entry without regular documents, of a certain Srafra Pietro, born in Turin in 1898, a communist. Please let us know whatever information you may have on the above-mentioned individual, there being no prior records corresponding to this name.

\footnotetext{
${ }^{9}$ The latter document - reproduced below - is dated Torino - 27-7 1922 and bears the entry stamp of the Ministry of the Interior with the date 31 July 1922, while the reference number of a second stamp Direzione Generale della P.S. Ufficio Riservato is 21138. al of 2 August 1922.

${ }^{10}$ In England, besides following lessons and workshops at the London School of Economics, Sraffa carried out research at the Labour Research Department (an offspring of the Fabian movement, although in 1921-22 it was very close to the newly constituted Communist Party of Great Britain).
} 
R. Prefecture of Turin

Turin 27-7-1922

Confidential protocol N.2419

Reply to Note-23-6-22 N.-17010

Subject SRAFFA (not Srafra) Pietro di Angelo e Tivoli Arduina, born in Turin on 5 August 1898 -

Communist

Right Honourable Minister of the Interior

Head Office of the State Police.

General and Confidential Affairs Department

Rome

In answer to the note in the margin I wish to inform of the Ministry that for Sraffa (and not Srafra) there are no previous records in the local Police Department.

He moved to Milan in 1918.

The Milan Police Department has given notification by letter dated 22 of this month $N$. 4415 that Sraffa has returned from London to the city, and professes communist ideas, which has led to quarrels with his father = Prof. Avv. Angelo, a staunch monarchist.

Sraffa has not as yet drawn attention to himself in Milan.

In England it appears that he was employed at a Bank, and that while he was there he was called by the Ministry of Public Works for work in Milan and Lombardy, the nature of which is not known.

The Prefect

\section{Ministero degli Affari Esteri, Archivio Storico Diplomatico}

Registro Affari Commerciali, sezione Italia, posizione 39, fascicolo Coordinamento Economico Sraffa Piero - Articolo contro le banche italiane.

Documents drawn up in December 1922.

The documents in question were drawn up subsequent to publication of the article by Sraffa Italian Banking To-day, which appeared in the supplement of 7 December 1922 in the series Recostruction in Europe of the Manchester Guardian Commercial. The supplement was published in four editions in different languages, including Italian, and edited by John Maynard Keynes.

The documents are conserved in a file entitled "Coordinamento Economico Sraffa Piero - Articolo contro le banche italiane” (Economic Coordination Sraffa Piero - Article against the Italian banks) which is inserted into another file entitled Calunnie contro l'Italia (Slanders against Italy). This dossier, in turn, besides the one on Piero Sraffa, contains another file entitled Campagna antitaliana all'estero sul credito e sui tributi italiani (Anti-Italian campaign abroad on Italian credit and taxes) bringing together 
cuttings from foreign newspapers and circulars to Italian diplomatic staff abroad dating to the years 1919-1920.

The folder concerning Sraffa contains a copy of the English edition of the Manchester Guardian Commercial supplement, the telegram sent by Angelo Sraffa (Piero's father) to Benito Mussolini on 21 December 1922 in reply to a non extant telegram sent by Mussolini to Angelo Sraffa on 20 December 1922, the manuscript text penned by Mussolini of a second telegram, sent to Angelo Sraffa on 21 December, a brief biographical note on Piero Sraffa, and the accidental impression on the sheet which contains the biographical note, from another sheet covering it, of parts of the manuscript penned by Mussolini of his first (non extant) telegram to Angelo Sraffa (the texts of these documents are reproduced in Naldi 1998b, pp. 288-89). ${ }^{11}$

Quoted below is the text of the letter (conserved in the Modern Archive Centre of King's College, Cambridge - JMK/L/S/5-6) in which Piero Sraffa informed John Maynard Keynes of Mussolini's reaction to the publication of his article Italian Banking Today. In this letter Sraffa provides a translation of the entire exchange of correspondence between his father and Benito Mussolini, and that translation is consistent with what can be reconstructed on the basis of the documents kept in the archive of the Ministry for Foreign Affairs (ASD), also including Mussolini's first telegram, the original of which has been lost, and a letter by Angelo Sraffa of 24 December 1922, our knowledge of which is confined to a copy kept in the Wren Library of Trinity College (Cambridge) in the Piero Sraffa Papers (Add.ms.a.158). ${ }^{12}$

\section{Private and confidential Milan, Xmas 1922}

Dear Sir,

it is my duty to inform you of a correspondence which has taken place between the Italian Prime Minister, signor Mussolini, and my father concerning my article on "Italian Banking to-day", published in the 11th Supplement to the Manchester Guardian Commercial.

On December 20th ultimo signor Mussolini wired to my father as follows:

"Professor Sraffa - Rector University Bocconi _ Milan

(Rome, 20th, 6.30 p.m.)

13032. My attention is called to and I read in the issue of December 7th, 1922 of the Manchester Guardian Commercial edited by Keynes an article by your son Piero

\footnotetext{
${ }^{11}$ Naldi 1998b did not cite a letter by Giuseppe Toeplitz (who was then managing director of the Banca Commerciale Italiana) contesting Sraffa's observations on the economic solidity of the Banca Commerciale Italiana. The letter was published on 29 March 1923 in supplement n.13 of the «Manchester Guardian Commercial». This supplement was part of a new series that, while adopting the new title of European Reconstruction, continued the numbering of the previous series (I owe thanks to professor L. Pasinetti for drawing my attention to this letter).

12 The accuracy of the information contained in Sraffa's letter to Keynes, doubts about which had been raised, also in consideration of arguments put forward by Renzo de Felice (see Finoia 1988, pp. 301-2 pages reproduced in Naldi 1998b, p. 271), is therefore fully vindicated by analysis of the documents conserved in the folder Coordinamento Economico Sraffa Piero - Articolo contro le banche italiane.
} 
which represents an act of true and simple banking defeatism an act of true and real sabotage of Italian finance the more grave as it is perpetrated in a newspaper published in many languages and with a world-wide circulation-Through you I mean to recall in the most forceful way your son to keep a wiser conduct and to remember that his being a socialist does not at all allow him to spread abroad mistrust in the institutions of Italian finance - I give warning that I reserve myself (io mi riservo) to demand with other means (in altra sede) very strict account of this scurvy act - I shall appreciate a reply by wire - Mussolini -."

My father replied, on December 21st, and wired that he was prepared to go to Rome, if signor Mussolini wished so. Signor Mussolini replied with the following telegram, dated December 21st:

"Angelo Sraffa - Bocconi University - Milan

(Rome, 21 st,7.20 p.m.)

13061 - Received your telegram - Please invite your son to write immediately article in same review such as to dissipate eventual (eventuale) ${ }^{13}$ pessimistic impression certainly (sic) caused by article concerned -Useless your journey Rome- Mussolini -"

On December 24th, my father wrote to signor Mussolini a letter in which the following statement, for which I am responsible, was related: "that being his article, published in the 11th, of the Manchester Guardian Commercial, Supplements, edited by Mr.Keynes, a pure and simple statement of figures and facts publicly known and not contradicted, he has nothing to rectify and nothing to add, and therefore cannot accede to the invitation to write a second article."

I am now waiting to see what action signor Mussolini is going to take in order to enforce his will.

The telegrams have been, very cleverly indeed, addressed to my father, who, of course, was not at all concerned in this matter; obviously it has been hoped that the fear of involving him in possible reprisals would make me docile or at least impede any publicity, which appears to be the most dreaded thing: to this extent the move has been successful. I am in consequence obliged to beg you to regard as strictly private and secret the content of this letter. It will be posted in Switzerland, as foreign letters are being opened for censorship; for the same reason please do not write to me at my usual address on this subject. I shall be obliged if you will acknowledge receipt of this present letter to:

P. SRAFFA - Poste Restante - LUGANO (Switzerland)

where I have made arrangements for letters being called for on January 3rd, 1923.

With best wishes for the new year,

I am,

Yours sincerely,

Piero Sraffa

${ }^{13}$ any possible would more properly translate eventuale. 


\section{Archivio Centrale dello Stato}

Ministero della Pubblica Istruzione, Direzione Generale Istruzione Universitaria, Liberi Docenti II serie 1910-1930, Busta 312, fascicolo Sraffa Piero

Documents drawn up in the period March 1925 - March 1926.

The file contains documents regarding the participation of Sraffa in the evaluation procedures for being entiteld to lecture as libero docente in "Political economy" in an Italian university. ${ }^{14}$ The title was effectively conferred on Sraffa on 13 November 1925 , but he did not collect the certification since, in the meantime, he had been appointed full professor at the University of Cagliari.

The report of the Board, consisting of Achille Loria, Augusto Graziani and Pasquale Iannaccone, ran as follows:

The scientific qualifications submitted by Dr. Piero Sraffa are neither substantial nor very numerous, but they show that he is able to address practical economic issues with sound scientific criteria and theoretical argumentation with an acutely analytical and critical approach. Above all the text on "Relazioni fra costo e quantità prodotta" ("Relations between cost and quantity produced") reveals the candidate's aptitude in addressing the no few considerable difficulties involved in the topic, which has been the object of discussion and complex investigation in the field of theoretical economics, and in seeking to resolve them with logical lucidity and critical acumen.

These intellectual faculties, which will certainly develop yet further with the extension of Sraffa's studies to a broader field, have been confirmed in oral discussion of both the topics addressed in the printed publications and of various topics further afield. Hence the Board has deemed it unnecessary to subject Sraffa to further oral examination, his didactic skills having been attested by the University of Perugia, where he teaches Political Economy and Science of Finance on a temporary contract.

In conclusion, the board has judged Dr. Sraffa competent for the post of Lecturer in Political Economy.

Rome, 13 November 1925

Achille Loria

Augusto Graziani

P.Iannaccone $e^{15}$

\footnotetext{
14 The Italian title of libero docente was analogous to the German Privatdozent.

${ }^{15}$ From a letter sent by Piero Sraffa to Raffaele Mattioli on 7 July 1957 we learn that when Sraffa met Jannaccone for the libera docenza examinations they touched upon the relationship between Sraffa's 1925 article on cost curves and Jannaccone's paper: «ho ricevuto la ristampa del 'Costo di prod.' di Jannaccone [...] quando lo lessi 30 anni fa (dopo che lui mi esaminò nella libera docenza e mi fece capire che avrei dovuto citarlo - e aveva ragione) mi sembrò importante» (Archivio Storico Banca Intesa San Paolo, Carte Raffaele Mattioli; I owe thanks to professor G. de Vivo for drawing my attention to this letter; see also Naldi 2004, pp. 257-60).
} 


\section{Archivio Centrale dello Stato}

Ministero della pubblica istruzione, Direzione generale dell'Istruzione superiore, Divisione 1, Serie 2, Concorsi a cattedre nelle università italiane, Busta 6, fasc. 141 Cagliari. Economia politica 1925.

Documents produced in the period December 1925 - February 1926

The file contains Ministry of Education documents regarding the appointment and activities of the Examining Board for the competition for the Chair of "Political Economy" at the University of Cagliari. A total of 11 candidates competed for qualification (Cesari Emilio; Chessa Federico; Fasolis Giovanni Battista; Fraccacreta Angelo; Grilli Carlo; Michels Roberto; Navarra Gaetano; Papi Giuseppe Ugo; Pinobranca Alfredo; Rosselli Carlo; and Sraffa Piero); the proceedings of the Board were approved by the Ministry of Education in February 1926.

Sraffa, who came second in the final classification, was called to take the Chair in the March of that same year.

Below is the last part of the report drawn up by the Examining Board, which consisted of professors Costantino Bresciani-Turroni, Attilio Cabiati, Augusto Graziani (chairman), Lorenzo Mossa and Umberto Ricci and met in Rome on 5, 7, 8 and 9 January $1926 .^{16}$

[...] SRAFFA - In charge of Political Economy at the University of Perugia as from the academic year 1923-1924 and at present also in charge of Science of Finance. In 1925 he was awarded a professorship in Political Economy. This candidate's scientific output is not a very plentiful: it amounts to no more than a report on the RELATIONS BETWEEN COST AND QUANTITY PRODUCED, a report on MONETARY INFLATION IN ITALY DURING AND AFTER THE WAR, an article published in the ECONOMIC JOURNAL on the Bank Crisis in Italy (dealing with the crash of the Bank of Sconto), an obituary on Pantaleoni, and a note on the SITUATION OF THE ITALIAN BANKS and the COMMERCIAL SUPPLEMENT TO THE MANCHESTER GUARDIAN. The Board reserved its praise mainly for the first of these texts, in which the author tackles one of the most challenging issues of Economics: nevertheless, it criticised the conclusions the author arrived at. It also observed that the Author's evident concern to appear succinct and concise has in some cases led him to laboured constructions and rigour bordering on obscurity. Clearly, however, the author already shows a capacity for forceful argumentation and penetrating criticism, displaying complete mastery of the literature on the subject dealt with. The article on the bank

\footnotetext{
${ }^{16}$ Conserved in manuscript and typescript form in the papers regarding the proceedings of the Board, it was published as Relazione della commissione giudicatrice del concorso per professore non stabile alla cattedra di economia politica nella R. Università di Cagliari, in the Official Bulletin of the Ministry of Education, Part II Administrative Proceedings, a. LIII, vol. I, n. 9, 4 March 1926, pp. 773-77 (the evaluation of Sraffa is on p. 776).
} 
crisis, and also the very short but meaty note in the MANCHESTER GUARDIAN bear out the author's aptitude in observing and astutely interpreting economic phenomena. The Board is therefore unanimous in recognising that this candidate is qualified for university teaching.

Coming to discussion on the relative worth of the candidates, and having reiterated their evaluation of the exceptional merits of Prof. Michels as sociologist and expert in Political Sciences, the Commission turned to examination of the remaining candidates. It was unanimous in forming a group apart of three candidates FRACCACRETA, GRILLI and SRAFFA, recognising them as distinctly superior others [sic!] and perfectly worthy of occupying a tenured university Chair.

Having made close examination of the academic and didactics qualifications of each of the three candidates mentioned above, as well as the scientific publications, the Board then proceeded to voting the shortlist of three. The result was as follows:

$I^{\text {st }}$ - GRILLI with 5 votes

$2^{\text {nd }}$ SRAFFA with 5 votes

$3^{\text {rd }}$ FRACCACRETA with 5 votes

$[\ldots]$

Subsequent to publication of the results of the competition, the Faculty of Law of the University of Cagliari decided to enter upon the procedures for the appointment beginning with the first of the three shortlisted by the Board and, should he forego the appointment, to go on to the following name:

In consideration of the competitions held for the Chairs of Science of Finance and financial law, political economy and history of Roman law at this university [...] the Faculty is unanimous in its decision: [...]

To propose for the appointment of Professor of political economy at the University of Cagliari Dr. Grilli Carlo; secondarily, should Grilli forego the appointment, Dr. Sraffa Piero; and, should both Grilli and Sraffa forego the appointment, Dr. Fraccareta Angelo. ${ }^{17}$

Although we have not been able to track down any documentary evidence, it seems certain that Carlo Grilli, then director of statistical service at the Ministry of Public Works, did in fact forego the appointment, which consequently fell to Sraffa.

\footnotetext{
${ }^{17}$ University of Cagliari, Faculty of Law, Archive, Register of the minutes of the Faculty Council, 22 February 1926, pp. 553-54.
} 


\section{Archivio Centrale dello Stato}

Ministero della pubblica istruzione, Direzione generale dell'Istruzione superiore, Fascicoli del personale insegnante e amministrativo, II Versamento, $2^{\circ}$ serie, Busta 150, fascicolo Sraffa Piero.

The file is empty.

The file of the Ministry of Education teaching staff were passed on to the Central State Archive in more than one accessions. The second transfer, as described in the note introducing the archival inventory drawn up by Claudio Santangeli, consists of two series. The first comprises files for staff who performed the activities between the end of the $19^{\text {th }}$ century and the 1930 s - mainly full professors and a small number of the administrative staff of the Universities. The second series, covering the same period, comprises by contrast relatively few dossiers for full professors and a far larger number of files for the administrative staff. The personal file for Sraffa, belonging to this second transfer, together with the one for his father Angelo, now appears to be missing. It should have contained documentation of Sraffa's university career, from his appointment as professor of Political Economy at the University of Cagliari as from March 1926, to his move to the University of Cambridge in July $1927^{18}$, and on to his resignation on 1 November $1931^{19}$. In fact, this latter date probably marked the closing of the folder and inclusion in the list of professors who had resigned from the appointment. Nevertheless, Sraffa was reinstated in his teaching role in 1950, effective

\footnotetext{
${ }^{18}$ Sraffa also taught at the University of Perugia from 1923 to 1926, and in 1927 won a competition at the Genoa School of Business (Scuola Superiore di Commercio) - which was in the charge of the Ministry of the National Economy (Naldi 1998a). The complex series of administrative procedures thanks to which Sraffa was able to spend in Cambridge the decades between 1927 and his retirement from the University of Cagliari (in 1973) can be reconstructed on the basis of documents conserved by the University of Cagliari and Trinity College, Cambridge and, with regard to his being placed at the disposal, between 1928 and 1931, of the Ministry of Education to begin with and then of the Ministry of Foreign Affairs, on the evidence of documents conserved in the fascicle described in Section 11.

${ }^{19}$ Coming into force on the same day was decree law 28 August 1931, n. 1227, Provisions on higher education, published in the Gazzetta Ufficiale (Official Gazette) on 8 October 1931, article 18 of which established the obligation, for ordinary professors and professors appointed in the Royal institutes of higher education, to swear an oath of loyalty «to the King and his Royal Successors and to the Fascist Regime» and commitment «to exercising didactic activities and fulfilling all academic duties with the aim of forming industrious and honest citizens, devoted to the Country and to the Fascist Regime». The concomitance between the coming into effect of the decree and Sraffa's resignation has also been pointed out by $\mathrm{H}$. Goetz, Il giuramento rifiutato. I docenti universitari e il regime fascista, Florence, La nuova Italia, 2000, p. 40, who added a short quotation of Sraffa himself, neither confirming nor denying the connection between his resignation and introduction of the obligation to swear loyalty to the regime. The draft of Sraffa's letter of resignation is conserved in Cambridge among the Sraffa Papers, which also include the draft of the previous letter of resignation, dated January 1931, but very similar to the one actually sent in November 1931 (which suggests that Sraffa, presuming that the obligation to swear loyalty to the regime would soon be brought in, was already prepared to submit his resignation). It is also to be seen that, contrary to what he stated in his letter of resignation, Sraffa had no teaching appointment in Cambridge in November 1931, but only a temporary appointment, which was to end within a few months, as curator of a library (Naldi 2005, p. 390).
} 
as from 1 November $1947^{20}$, remaining in service as supernumerary professor until 1973. Presumably, then, the file closed in 1931 would have been used in examining Sraffa's application for reinstatement, and the documentation conserved in his old personal dossier would have been incorporated in a new file, which probably remained with the Ministry of Education.

\section{Archivio Centrale dello Stato}

Direzione generale di Pubblica sicurezza, Divisione affari generali e riservati, Casellario Politico Centrale, Busta 4927, fascicolo 63323 Sraffa Pietro.

Documents drawn up in the period January 1927 - December 1941.

The documents contained in this file can be divided into four main groups: (1) documents produced in the period January-March 1927 regarding the remittance of the sum of a thousand lire by Piero Sraffa to Antonio Gramsci (then confined to the island of Ustica) with a postal order; (2) documents drawn up in the period May 1931-March 1938, also with the involvement of the Italian Consulate in London, subsequent to reports of contact had by Sraffa (described as a «communist also belonging to the revolutionary movement "Giustizia e Libertà"» - a liberal-socialist movement founded in Paris by antifascist exiles) with antifascist groups in Paris, and subsequent entry of his name in the "Rubrica di frontiera" (Frontier Directory) (N.26400) with the provision that he be detained on entering Italy; ${ }^{21}$ (3) documents drawn up in the period January 1935-April 1937 regarding the occasions on which Piero Sraffa went to see Antonio Gramsci (then granted conditional release), first in the Cusumano clinic, in Formia, and subsequently in the Quisisana clinic, in Rome, after which he was interrogated by police officers about the contents of the conversations; (4) reports drawn up in the period April 1935-April 1937 prompted by various circumstances: letters that Sraffa exchanged with Antonio Pesenti (whose correspondence was inspected by the Prefecture of Sassari); identification of an envelope sent from France to the Milanese address of Piero Sraffa's father containing a copy «of the antifascist periodical "Giustizia e Libertà"» (JuneNovember 1936); a request for information sent by the London section of the "Unione nazionale ufficiali in congedo d'Italia" (National Union of Discharged Officers of Italy), in which Sraffa had applied to be enrolled (February-June 1937); a request for information on «the Jew Piero Sraffa son of Angelo, no better indicated, at present resident in London», which the "Comando Supremo S.I.M." (Italian military

\footnotetext{
${ }^{20}$ University of Cagliari, personal fascicle Sraffa Piero; Sraffa Papers, B16/1. His reinstatement, on the basis of decree laws n. 255 of 7 September 1944, n. 238 of 5 April 1945 and n. 535 of 27 May 1946, made explicit reference to having «however [ceased] service to avoid swearing the oath of loyalty to the fascist regime».

${ }^{21}$ As emerges from the documentation conserved in the same file, this provision was modified in September of the same year 1931 to the effect that «rather than detained he be reported and watched closely to ascertain activities contacts».
} 
intelligence) sent to the Public Security Headquarters of the Ministry of Internal Affairs (October-December 1941).

Quoted below is the text of the letter which apparently had to do with the decision, in January 1927, to open a file headed Piero Sraffa in the Political Records of the Public Security Headquarters, soon to be transformed into the "Casellario Politico Centrale" (Central Political Records Office).

\section{R.Prefecture of Palermo}

Cabinet

Palermo, 22 January 1927 (year V.)

Ministry of Internal Affairs - Public Security Headquarters

Rome

In relation to the telegraphic circular $9^{\text {th }}$ inst. N.1060 I wish to notify the Ministry that on the $10^{\text {th }}$ of this month there arrived here in transit from Milan the following telegram addressed to Ustica:

"“ N.I. from Milan postal order savings Prov. di Milano (Province of Milan) pay thousand lire to Antonio Gramsci for Piero Sraffa thousand lire Liborio."”.

The Police Department of Milan, contacted for the purpose, has made it known that the sender of the postal order is Prof. Sraffa Pietro, who teaches political economy at the University of Cagliari, and who states that he became acquainted with Gramsci in Turin, where they studied together, and who, out of simple generosity, complied with the request for money made telegraphically by the said person.

The above-mentioned Police Department adds that Sraffa used to profess subversive ideas, but that since he has been living with his parents he has not given cause for concern.

The Prefect

This letter, which dates to 10 January 1927 the transfer of 1000 liras to Antonio Gramsci and refers to a telegraphic communication of the previous day which it has not been possible to trace, bears the register stamp of the Political Records of the Public Security Headquarters «28 Gen 1927 N.2508/S» and a handwritten note saying: «reference made for Gramsci» ${ }^{22}$ and «register file». ${ }^{23}$ We may therefore conclude that subsequent to this communication it was decided to open a dossier dedicated to Sraffa in the Political Records of the Public Security Headquarters. However, it is also to be noted that another document conserved in the same file of the Central Political Records shows that on 15 January 1927 the Prefecture of Milan answered to a request for

\footnotetext{
${ }^{22}$ In the file in the Central Political Records dedicated to Antonio Gramsci there is in fact a reference to this document (see Section 9 below).

${ }^{23}$ A cross-reference mark connects this note to the words of the text «Sraffa used to profess ideas».
} 
information about Sraffa sent by the Public Security Headquarters on 25 December $1926 . .^{24}$

\section{Archivio Centrale dello Stato}

Direzione generale di Pubblica sicurezza, Divisione affari generali e riservati, Casellario Politico Centrale, Busta 2499, fascicolo Gramsci Antonio.

Documents drawn up in the period January 1927 - January 1935.

This substantial dossier contains documents concerning the police surveillance of Antonio Gramsci. It can be divided into two chronological batches: the documentation up to October 1926, and then following upon his arrest. The first consists of a biographical dossier, reports on his movements in Italy and abroad, and information about the role he played in the Psi (Italian Socialist Party) to begin with, and subsequently in the Pcd'I (Communist Party of Italy); far more varied are the documents drawn up as from November 1926, containing reports first on his transfer from one prison to another, and then to the clinics in Formia and Rome, as well as confiscated correspondence and the manuscripts of petitions by Gramsci himself and members of his family addressed to Mussolini and top-ranking officials in the Ministries of Internal Affairs and of Justice.

In this file the name of Sraffa appears only three times. The first time it appears in a preprinted form filled in by hand and with the registry stamp "Direzione Generale di P.S. Schedario Politico" (Public Security Political Records Headquarters) dated 28 January 1927 (N.2508/S), referring to his remittance of the sum of thousand lire to Antonio Gramsci, at Ustica. Here is the text (the handwritten parts in italics):

\section{Gramsci Antonio in political Confino at Ustica}

The Prefect of Palermo with note N 6 of 22-1-1927 notifies that the confinato mentioned above has received a postal order of a thousand lire from Sraffa Pietro.

See in Cat. $2^{\circ}$ N 2508/S - 28-1-1927 Entry Sraffa Piero

The name of Sraffa appears again in 1935, in relation to his visits to Gramsci in Formia. Reported in a note dated 31 January 1935 and addressed to the Ministry of Foreign Affairs and the National Ministry of Education is the interrogation which Sraffa underwent on 6 January after his visit to Gramsci at the Cusumano clinic. ${ }^{25}$ The record

\footnotetext{
${ }^{24}$ A handwritten note on that answer, which referred to Sraffa only as a «teacher of political economy in the University of Cagliari», reads: «Nothing» and «nothing for 3 years 1st section», while a stamp with the date 20 January 1927 reads «Nulla Archivio Riservato» (Nothing Reserved Archive). Another stamp («Public Security Headquarters Classified Material Office - Reference N 1184 S entered 19-1-1927») is crossed with a blue pencil mark.

${ }^{25}$ Other copies of this document are kept in the file of Casellario Politico Centrale in the name of Piero Sraffa and in the file which will be considered in Section 13 below.
} 
of the interrogation includes an account of Sraffa's movements and meetings on returning to Italy for the Christmas holidays (particular emphasis is given to the visit made to his uncle Mariano D'Amelio), and of his conversation with Gramsci on «old common acquaintances and matters of history and literature. We also talked - Sraffa continued in the interrogation - about Gramsci's legal status in relation to the various amnesties and pardons of the last few years and the possibility of obtaining a further reduction of the sentence». The police official, however, deemed this latter part of Sraffa's statement to be «mendacious» since, «being only on probation», Gramsci could not benefit from «any reduction of sentence, as he has no sentence to serve». Moreover, the police official went on, «seeing that both Sraffa and Gramsci are intelligent, quickwitted persons and are doubtless acquainted with the relevant legal provisions, the possibility that they talked about this matter on the occasion of their meeting is to be ruled out ».

Again in relation to the visits made to Formia, Sraffa is reported as having met Gramsci on 31 August 1935 in a note dated 3 September 1935 sent by the Rome Police Headquarters addressed to the Political Records Office and registered on 10 September 1935. There are no references subsequent to this date.

\section{Ministero degli Affari Esteri, Archivio Storico Diplomatico Ministero della Cultura Popolare, Gran Bretagna 1926-1927, Busta 712, fascicolo Manchester Guardian e Daily Herald}

Documents drawn up in the period October - November 1927.

The file contains documents drawn up by the Italian Embassy in London and the Press Office of the Ministry of Internal Affairs ${ }^{26}$ subsequent to publication in the newspaper the Manchester Guardian of two letters sent by Sraffa: the first, published on 24 October 1927, was signed "An Italian in England" and had to do with the detention of Antonio Gramsci; the second, published on 25 October 1927, signed "Piero Sraffa", was presented as prompted by some observations by George Bernard Shaw on the anticapitalist nature of the actions of the Italian government, published some days earlier also in the Manchester Guardian. The first letter was to have been published anonymously but an index published on the same day although not on the same page as the letters to the editor but detailing the contents of it gave the name of Piero Sraffa as the author. As a remedy for this error, Sraffa, in agreement with the editorial staff, immediately sent a second, politically neutral, letter (the Italian Embassy in London

\footnotetext{
${ }^{26}$ The documents drawn up by the Press Office of the Ministry of Foreign Affairs found their way into the archives of the Ministry of Popular Culture (created in May 1937) through successive transformations of the Press Office of the Head of Government (instituted in 1922), of the Undersecretariat of State for the Press and Propaganda (instituted in September 1934) and of the Ministry for the Press and Propaganda (instituted in June 1935).
} 
described it as of very limited importance), which was published under the same heading as the first (The Methods of Fascism) to justify the presence of Sraffa's name in the index of the previous day. ${ }^{27}$

In the case of the first letter, considered anonymous, the information sent by the Italian Embassy in London to the Ministry of Foreign Affairs gave rise to a communication to the Ministry of Internal Affairs, which considered possible steps to be taken but apparently took none. ${ }^{28}$ In the case of the second letter, we may deduce that an original report that may have specified only the author's surname ${ }^{29}$ prompted a request by Mussolini (probably made through Dino Grandi - at the time undersecretary at the Ministries of both Foreign Affairs and Internal Affairs, both ministries coming directly under the head of government) to clarify whether the Sraffa in question was in fact Piero Sraffa. ${ }^{30}$

Below is the text of the answer given to Mussolini's request by the Italian ambassador to London:

\section{Italian Embassy}

London

Telespresso $N^{\circ} 3353 / 1290$ st

Ministry of Foreign Affairs

Rome.

London, 2 November 1927 year $V$.

Piero Sraffa.

Telegram from H.E. $N^{\circ} .8164 / 613$.

\footnotetext{
${ }^{27}$ The incident is reconstructed in Naldi 1998a and Naldi 2000; the latter quotes the texts of both letters.

${ }^{28}$ The document containing this communication is conserved in ACS Ministry of Internal Affairs, Public Security Headquarters, General and Classified Affairs Division, Foreign Press, F4, Envelope 22 file Daily Herald. Reception of this information prompted a further note, conserved in ACS Ministry of Internal Affairs, Public Security Headquarters, General and Classified Affairs Division, Foreign Press, F4, Envelope 56 Folder Manchester Guardian and in the folder of the Central Political Records dedicated to Antonio Gramsci. In these documents, too, the name of Sraffa finds no mention and the letter of 24 October is treated as anonymous. The significant part of the first communication, dated 25 October 1927, runs: «The "Manchester Guardian" publishes a letter signed by an Italian in England in which it is stated that despite his extremely poor conditions of health the former member of parliament Gramsci is being transferred to Rome to be tried». The second note was drawn up using a preprinted form; the significant part of it runs (the handwritten parts are in italics): «The Ministry of Foreign Affairs with note N. 5876 of 25 Ottobre 927 has consulted this Office for the appropriate steps to be taken [considering] that [the] newspaper Manchester Guardian having subversive and anti-Italian characteristics has published a letter signed by an Italian in England in which it is said that despite his extremely poor conditions of health the former Member of Parliament Gramsci is being transferred to Rome to be tried».

${ }^{29}$ The original report, evidently supplied by the Italian Embassy in London, does not appear to have been conserved

${ }^{30}$ The same dossier also contains a letter addressed to Benito Mussolini sent by Oscar Levy, the author of another letter to the editor published by the Manchester Guardian on the same day of 24 October. This letter was favourable to fascism and - to show it to Mussolini - the author attached the entire page of the newspaper; this page also contained the letter on the detention of Antonio Gramsci signed An Italian in England and a letter by Gaetano Salvemini, but in this case no one of these letters seem to have received particular attention from the Italian addressees.
} 
I confirm the letter published Manchester Guardian 25 this month is signed Piero Sraffa.

In my telegram $N^{\circ} .760$ I limited myself to specifying only surname Sraffa given that doubt expressed in the telegram from H.E. $N^{\circ} .598$ concerned only surname and not name Piero.

I enclose Sraffa letter text whose importance, anyway, appears very limited.

Bordonaro

The document quoted, which is also conserved in a typed copy, is attached to a card signed in pen Grandi (in the handwriting of Dino Grandi) and proceedings (in pencil and, presumably, by another hand) - bearing preprinted text no further completed, running:

Ministry of Foreign Affairs

For the attention of H.E. the President

Rome, 192

\section{Ministero degli Affari Esteri, Archivio Storico Diplomatico Archivio Scuole Cat.IV, 1929-37, Busta 858, fascicolo Sraffa Pietro}

Documents drawn up in the period November 1928-May 1937.

The documents contained in this file can be divided into three main groups: (1) documents produced in the period November 1928-January 1931 further to the request made by Sraffa to the Ministry of Foreign Affairs to be placed at the disposal of that Ministry, in accordance with decree law n.2321 of 19 December 1926, in order to continue the teaching activity for which he had moved to Cambridge in the summer of 1927. This request also had the support of the secretary of senator Mariano D'Amelio (First president of the Supreme Court and uncle to Sraffa). The request was granted both on the first application and for the successive renewals, despite the contrary opinions expressed on various occasions, mainly by officials of the Ministry of Foreign Affairs and, presumably, the secretary of the "Fasci italiani all' estero" (Italian Fasci abroad), while favourable opinions came from the Italian Embassy in London - at the centre of these differing opinions were the political leanings of Piero Sraffa; (2) documents produced in the period March 1931-January 1932 subsequent to information reported by the Ministry for Internal Affairs on relations between Piero Sraffa and "Giustizia e Libertà" (considered in greater detail in Sections 8, 13 and 14). In this case, besides the Ministry of Foreign Affairs, the Italian Embassy in London and the National Education Ministry (Ministero dell'Educazione Nazionale, formerly Ministero dell'Istruzione) were also involved, with the same differences of opinion as seen before. The exchange concluded with recognition that Sraffa had by then resigned from his role as professor at the University of Cagliari and the consideration that it was not advisable to set 
limitations to his freedom of movement in Italy - also in this case, as in the case described above, the London Embassy appears to have favoured a less restrictive line (particularly interesting in this respect is a communication from the London Embassy dated 31 December 1931 referring to the occasion when on returning to Italy Sraffa, despite indication in the 'Rubrica di frontiera', a register of suspect travellers, that he should be stopped, was able to pass the border unhindered - see Section 15). The Embassy took a positive view of Sraffa's stay in England also subsequent to a census of Italian professors residing abroad promoted by the Ministry of Foreign Affairs in May 1933; (3) the last documents in this series (covering the period January 1935-May 1937) reflect the correspondence between the Ministry of Internal Affairs and the Ministry of Foreign Affairs and the Italian Embassy in London regarding police interviews consequent upon the meetings that Sraffa had with Antonio Gramsci in the clinics of Formia and Rome.

On the evidence of the documents sent to Rome, the London Embassy and Consulate do not seem to have been well informed of Sraffa's posts and academic activities: for example, he was considered to be employed as lecturer or library director when in reality had neither of the posts at the time; he was also said (in May 1937) to have already published fourteen volumes for Riccardo collaboration when his work as editor of the writings of David Ricardo had not actually led to the publication of any volumes. Below is the text of a note (the manuscript parts not in italics) attached to a communication of December 1928 from the Ministry of Foreign Affairs' Directorate General of Italian Schools Abroad to the Ministry of Education expressing an opinion favourable to Sraffa being placed at disposal. Evidently, having perused this note a higher official wrote down on the same paper: Suspend:

Urgent

Ex-Socialist

son of Prof Sraffa expert in business law, mason

gave no cause in Milan

the father is brother-in-law of d'Amelio who apparently procured him the good graces of H.E. Rocco.

The outcome is summarised in a confidential letter from the Ministry of Foreign Affairs to the Italian Embassy in London:

Ministry of Foreign Affairs

Directorate General for Italian Schools Abroad

Ref. N. 2439/2

To the Embassy [London]

Re:

Prof. Piero Sraffa

Rome 25 Mar 1929 Year VII

Classified 
In response to the keen interest shown by H.E. the First President of the Supreme Court of the Kingdon, this Ministry has asked the Ministry of Education (Pubblica Istruzione) to place at its disposal Prof. Piero Sraffa, of the University of Cagliari, to continue the course in Political Economy at the University of Cambridge.

The Minister of Education gives notification that with the present provision the request is granted and that the said professor will, during the period granted - from 1 January to 31 December 1929 - also retain his role as nonpermanent professor in active service as far as his career and economic treatment are concerned.

Since this provision does not put to rest the reasons for this Ministry's diffidence regarding Sraffa's attitude towards the Regime, Your Excellency is asked to arrange for him to be kept under discreet and constant surveillance, reporting to this Ministry as the occasion arises.

What follows is the text of a letter sent by the Correspondence Service Office 1 of the Ministry of Foreign Affairs to the Directorate General for Italian Schools Abroad of the same Ministry accompanying a note by the Ministry of Education which suggested that Sraffa, because of information on his political attitudes received from the Ministry of Internal Affairs, was no longer kept at the disposal of the Ministry of Foreign Affairs.

Ministry of Foreign Affairs

Correspondence Service Office 1

$322335 / 1493$

To the Directorate General for Italian Schools Abroad

Memorandum

With regard to Memorandum n. 813673/917 of 16 June last, we are pleased to pass on to you, for any action you may have to take, a note of the Ministry of Education regarding the well-known Prof. Sraffa.

To inform you of the steps so far taken with regard to the Professor we are pleased to send for inspection the dossier that concerns him.

It emerges from this document that the steps taken by this Ministry, to the effect that if Sraffa returned to the Kingdom it would be impossible for him to go back abroad, have had no practical consequence in that while Sraffa is seen to have returned to the Kingdom, he has been able to leave it freely and with no control.

Rome, 25 Nov. 1931 Year X

\section{Archivio Centrale dello Stato}

Ministero dell'Interno, Direzione generale di Pubblica sicurezza, Divisione Polizia politica 1927-1944, Materia, Categoria K, Busta 105, fascicolo 1 K 56/11 Giustizia e Libertà, Sraffa Pietro, 1929-1931.

The file is empty. ${ }^{31}$

\footnotetext{
${ }^{31}$ This file has been mentioned for the first time in Canali 2013, p. 53
} 
The dossier's inside front cover bears a handwritten note in red pencil: "Records transferred into file $\underline{\text { Sraffa Pietro }-1 " . ~}$

The archive of the Political Police division (PolPol), instituted on the basis of decree law 9 January 1927, n. $33^{32}$, was organised in three series: personal dossiers dedicated to persons being watched, dossiers by subject matter and dossiers on the informers ${ }^{33}$. In the series by subject matter, the documents were subdivided by issues or categories; the various categories were distinguished by letters of the alphabet. For example, letter A corresponded to the files of the Political Police staff, while collected under category $\mathrm{C}$ was documentation regarding activities carried out abroad by refugees and subversives. Classified under category $\mathrm{K}$, on the other hand, were all the documents regarding the political parties.

Category K proved to be extremely weighty and was in turn divided into subcategories; K56, for example, was dedicated to 'Giustizia e Libertà'. The first fascicle of this subseries was found to be dedicated to Sraffa, although the cover displays the original press mark K56/11 (i.e. the eleventh fascicle of the subcategory). A note in red pencil on the inside cover reads: "Records transferred into folder Sraffa Pietro - 1", indicating that the fascicle was shifted from the "Subject matter" series to that of "Personal dossiers". It is worth noting that, on examining the personal files included in subcategory K56, Sraffa's is not the only one found to be empty: among those transferred to the personal category were, among others, fascicles n. 14 dedicated Luzzatto Fabio (K56/34), n. 17 dedicated to Torquandi Nello and Cristofani Raffaello (K56/39), and n. 19 to Arma Luigi (K56/41). Unlike these latter examples, however, Sraffa's is not to be found in the series of personal dossiers. Nevertheless, with further research the relevant documentation was tracked down; the file had in fact been incorporated, probably in the early 1950s, with the ad nomen file in category Z (see Section 13).

\section{Archivio centrale dello stato}

Ministero dell'Interno, Direzione generale di Pubblica sicurezza, Divisione affari riservati, Categorie permanenti, Categoria $Z$ "Anarchici, socialisti, comunisti, fascicoli personali 1949-1965”, b. 557, fasc. Sraffa Piero.

Documents drawn up in the period March 1931 - March 1959.

\footnotetext{
${ }^{32}$ Actually, a political investigation service had already been instituted with the "Testo unico di pubblica sicurezza" (decree law 6 November 1926, n. 1903). On policing in the fascist period, see Tosatti 2009, pp. 182-200.

${ }^{33}$ At the time of writing only the fascicles belonging to the first two categories appear to be conserved in the Central State Archive (http://www.guidageneralearchivistato.beniculturali.it).
} 
In 1948, in the context of the overall reorganisation of the Public Security Directorate General underway as from $1946^{34}$, the Division of Classified and General Affairs was divided between a General Affairs Division and a Classified Affairs Division. The latter, responsible for surveillance, prevention and repression of actions deemed harmful for the security of the State and the democratic order ${ }^{35}$, started upon - or rather, in reality, continued - the collection of information on and surveillance of single individuals. The fruit of this activity was to be seen in thousands of fascicles bearing the names of individuals, as well as the new Central Political Records Office; the fascicles classified with the letter $\mathrm{Z}$ were filled with information on subversives, anarchists and communists, mainly with reference to the post-war period. However, some cases saw incorporation in Republican Italy's documentation of material from the preceding period, and in particular from both the Records Office and the fascist Political Police ${ }^{36}$. Such is the case of the fascicle dedicated to Sraffa, into which the personal fascicle kept by the fascist Political Police was also inserted ${ }^{37}$. Of this there can be no doubt, for two compelling reasons: to begin with the documents regarding the period from 1931 to 1935 are contained within the old green folder of the PolPol with the heading "Ministry of Internal Affairs, Public Security Directorate General, Political Police Division" and classification in the top left corner as "Cat.[egoria] 1"; moreover, all the documents contained in this file display the pressmark K56/11, indicating the classification of the dossier in its original position.

We may therefore reasonably suppose that the documentation of the 1930s was incorporated into the new file opened by the Classified Affairs Directorate on 1 September 1951; this, in fact, is the date of a note on Sraffa, written in English, which runs «other services - get info old files». Probably, in response to a request for new information - apparently made in the context of a report from a British source - it had been considered appropriate to refer back to the old fascicle of the Political Police. Thus two sets of documents can be distinguished in the file: those relative to the 1930s and those of the $1950 \mathrm{~s}^{38}$.

The former set, conserved in its original state, opens with the following document (the parts not in italics are in manuscript, added to a typewritten text), clearly connected with documents already mentioned in Section 8 and with others, explicitly mentioning British Police, which will come under consideration in Section 14:

\footnotetext{
${ }^{34}$ This date, in fact, saw the creation of the Division for Special and Information Services (SIS), which was also entrusted with control of the new Central Political Records Office. See Tosatti 2009, pp. $230 \mathrm{ff}$.

35 The information provided here was drawn from the general guide of the Italian State Archives (http://www.guidageneralearchivistato.beniculturali.it).

36 For description of the series, see the online file by L. Garofalo and G. Pontecorvo, in http://search.acs.beniculturali.it/OpacACS/inventario/IT-ACS-AS0151-0000001.

37 This shows how mistaken was Mauro Canali's theory that the personal file of the political police dedicated to Sraffa is missing because «vanished away during the regime or immediately after» (Canali 2013, p .53).

${ }^{38}$ References to reports from British sources, in documentation produced both in the post-war period and in the 1930s, suggests that a fascicle dedicated to Piero Sraffa was probably kept in the British police archives, but so far no trace of it has been found.
} 
A reliable confidential source reports the following:

«The British Embassy in Paris reports a certain Sraffa Pietro born in 1898 in Turin, Professor at the University of Cambridge (England) as a militant communist and member of the group "giustizia e libertà". His father, named Angelo, is also a professor and lives in Milan.

Sraffa Pietro lived in Paris at the Hotel Monsigny, in Rue Monsigny n. 1 from 7 to 8 October 1930 and from 13 to 14 January 1931. The said person is a friend of the entire band of Rosselli, Lussu \& Co». ${ }^{39}$ Please avoid any verification in Paris regarding the state of Strasfa's [sic.] stay there as information is certain.

Head of D.

This document is followed by reports and notes regarding examination of the post sent to Calogero Tuminelli and Angelo Sraffa, but above all seeking information about Piero Sraffa. Notable among the documentation conserved is the copy of a letter sent on 15 August 1931 by the Ambassador to London, Antonio Chiaramonte Bordonaro, to the Public Security Division (and from the latter, in a copy, to the Political Police on 19 September). Part of the text is quoted below:

I fully appreciate the considerations that Your Excellency has kindly conveyed to me with cablegrams N. 313044/82 of 16 July last and N. 314677/94 of 8 of this August.

I cannot, however, agree with the proposal of the Minister of Internal Affairs to proceed directly to detention of Prof. Piero Sraffa should he return to the Kingdom. If, as seems to be the case, Sraffa is exceedingly wary in all his dealings, it hardly seems likely that he should be so ingenuous or foolhardy as to cross our borders with documents or anything else that may prove compromising.

The result of detention and search would be negative. And, at the end of his leave, Sraffa could not be denied authorisation to depart once again from the Kingdom and return to his post in Cambridge as long as he continues to enjoy the provision that places him at the disposal of the Ministry of Foreign Affairs as from 1 January of this year, for reasons of teaching in England.

\footnotetext{
${ }^{39}$ The same point, as we have already seen in Section 8, was reported in documents kept in the folder on Piero Sraffa in Central Political Records; but in that document no reference appears to the role played by the British Embassy in Paris. A meeting in Paris between Sraffa and Carlo Rosselli is mentioned by the latter in a letter to his brother written on 17 January 1931 (Ciuffoletti 1997, p. 513). Many years later, asked by Helmut Goetz about that episode, Sraffa answered: "Rosselli and I were friends when I was in Milan. I went to see him only one time in Paris, after which I was interrogated and had my baggage searched every time I re-entered Italy. On the contrary, I often met with Italian communists in Paris (even though I was not a Party member), but they, unlike Rosselli, were far more cautious" (Piero Sraffa to Helmut Goetz, 22 January 1974, Goetz Archive; draft in Sraffa Papers C111). It may be mentioned that in a November 1935 report of the British police on meetings Clemens Palme Dutt (member of the British communist party) had had in Cambridge, Piero Sraffa is not identified: «He has been to Cambridge and has seen BERNAL, (?) SOUFFA, DOBB, NEEDHAM, and others» (National Archives, London, $\mathrm{KV} / 2 / 2504 / 42$ ).
} 
I cannot see what truly positive result the Ministry of Internal Affairs expects to achieve by proceeding in this way. Apart, that is, from most certainly aggravating Sraffa, making him even more wary and, finally, creating infelicitous impressions in Cambridge University circles. In my subordinate opinion it would, on the other hand, probably be more advantageous to keep the person in question under close and discreet observation during his stay in the Kingdom; this could, in fact, in the eventuality lead to concrete results rather better than the procedure discussed above.

As regards the political conduct of Sraffa in this country, I can confirm that no negative information regarding him has been received by this Embassy, or indeed elsewhere. His relations with this Office have been limited to brief communications regarding his university appointment or requests for help in accessing books and documents in libraries in the United Kingdom. I do not think I have ever seen him or met him personally $[\ldots]^{40}$.

As for Sraffa himself, I am of course in full agreement with Your Excellency in the conviction that anyone teaching abroad must give absolute guarantees of support for the regime. If Sraffa fails to give such guarantees or falls short in doing so, it will suffice in due course not to renew the provision placing him at the disposal of the Ministry for teaching abroad.

A possible worry that must be taken into account, however, is that subsequent to any provision of ours adopted without sufficient motivation or too abruptly the person in question might prompt and obtain a permanent appointment at the University of Cambridge, where in fact Keynes, who knows him and has high regard for him, rules the roost. In other words, foregoing his career in Italy he might become an antifascist personage in England, like Crespi, and become a headache for us in such sensitive parts as the university environment.

I need hardly repeat that in the meanwhile I will do my best to ascertain what Sraffa's activity actually is and to what tendentious actions the charges brought against him may be imputed.

I will not fail to report further to Your Excellency.

Bordonaro

The second set of documents dates to the 1950s and also offers significant information. While an early note dated 3 September 1951 recapitulates the information of the previous years (the connection with Gramsci and the dispatch of 1000 Liras in 1927, the 1931 report describing him as a «man liaising between the Communist Party and the "Giustizia e libertà" groups»), the subsequent documentation refers mainly to requests for news on Sraffa, his connections with the Italian Communist Party and the reasons behind his journeys to Italy. Alongside the more strictly informative documents we find

\footnotetext{
${ }^{40}$ The part omitted refers to the request made by the Embassy, also in consideration of the presence in Great Britain of active anti-fascists including Gaetano Salvemini, don Luigi Sturzo and Angelo Crespi, to restore the funding for investigation and surveillance activities which the Ministry of Internal Affairs had recently suspended.
} 
others of different kinds, such as the transcription of the communique of the newspaper l'Unità about the members of the Honorary Committee created on the occasion of the $1^{\text {st }}$ Conference of Gramscian studies of 1958 , which included Sraffa.

As an example of the type of documentation conserved, here is the text of a note dated 22 October 1951:

\section{N. $224 / 2387026.10 .1951$}

\section{SECRET}

Prof. Piero Sraffa, who teaches at Cambridge and is a personal friend of TOGLIATTI, is suspected of being a clandestine delegate of the Italian Communist Party, assigned to participate in the "World Peace Congresses" held on the other side of the Iron Curtain.

He recently went to Prague to take part in a Kominform session as Italian delegate replacing Senator Eugenio REALE, who appears to have fallen into disgrace with the Communist leaders, suspected of doublecross in favour of the government in power. ${ }^{41}$

Updating on progress.

\section{Archivio Centrale dello Stato}

Ministero dell'Interno, Direzione generale di Pubblica sicurezza, Divisione affari generali e riservati, categorie annuali, 1930-31, K1B (Partito comunista all'estero), Busta 419, fascicolo Inghilterra.

Documents produced in the period March - December 1931.

The file contains documentation (correspondence, reports and notes) regarding police investigations on Sraffa and reports sent by the Ministry of Foreign Affairs and various Italian Prefectures, in particular Milan and Cagliari. The documents can be divided into two batches; the first batch consists mainly of correspondence and information notes seeking to ascertain Sraffa's role and activities within the antifascist movement. The request for investigation and information was prompted by a report of the British police and corroborated by an informer of the Italian political police. The documents show a tendency to place emphasis on the connection between Sraffa and the band led by Carlo Rosselli and Emilio Lussu, and his role in liaising between the communist movement and Giustizia e Libertà; consequently, documents referring to him in this period have been found both in the documentation concerning Giustizia e Libertà (category G1 Associations) and in category K1B, i.e. the subcategory with which were classified the documents regarding the communist movement abroad ${ }^{42}$.

\footnotetext{
${ }^{41}$ Sraffa, as emerges from his pocket diary for the year 1950-1951, in June 1951 spent some days in Prague (Sraffa Papers E23). Sraffa's annotations in his pocket diary suggest that he took part in a meeting in preparation of the international economic conference to be held in Moscow in April 1952, where he was to partecipate as a member of the Italian delegation.

${ }^{42}$ After 1931, however, documentation on Sraffa was held mainly in category K1B; see the years 1932 (envelope 35), 1933 (envelope 26), 1936 (envelope 37) and 1937 (envelope 67). Since the documentation
} 
The second batch of documents has to do with reports and surveillance on Sraffa's entering in Italy, and the telegrams regarding his journeys and travels between Rapallo and Milan. Initially, for Sraffa, listed n. 26400 in the register of suspect travellers (rubrica di frontiera), there stood the above-mentioned order to stop him on his return to the Kingdom. This order was probably given directly by Mussolini, as suggested by the memorandum dated 25 May 1931 (registered 13 May 1931) quoted below. This memorandum is essentially based upon a report sent by Stokes to Guido Leto dated «Roma 12 March 1931» and displays in the left-hand margin the stamped legend «CONFERRED WITH H.E. THE HEAD OF THE GOVERNMENT», followed by the manuscript addition «when he returns to Italy, stop him». ${ }^{43}$

In March of this year this Ministry received from the British Police confidential information that a certain Prof. Piero Sraffa, a student at King's College, Cambridge, was a communist, also belonging to the revolutionary movement "Giustizia e Libertà". It had been ascertained that Sraffa's father is Prof. Angelo Sraffa and that Piero Sraffa had business relations through the French and Italian Bank with a certain Dr. Tummicelli.

The British police concluded that Piero Sraffa had relations with various antifascist groups in Paris. At the same time the news had been sent from the British Embassy in Paris to the police authorities; reporting it, an informer of evidently utmost seriousness added that Sraffa had recently been to the French capital on two occasions and was a friend of the whole band of Rosselli, Lussu \& Co.

Having identified the Sraffa reported as Piero Sraffa, professor of political economy in the University of Cagliari, it was ascertained that in 1927 he had sent 1000 liras to the communist former Member of Parliament Gramsci, who was then "confinato". He had justified this as a simple act of friendship, while the Prefecture concerned then reported that Sraffa had professed subversive ideas. It was also ascertained that Sraffa was in fact living in England, with the official appointment entrusted to him by the Ministries of Foreign Affairs and Education, to teach political economy in the University of Cambridge.

The Prefect of Milan, called upon to carry out investigation subsequent to the report sent to the Ministry, reported back that Prof. Sraffa had been living in England since 1927 and that, before then, he had done nothing of any political significance apart from sending money to the former Member of Parliament Gramsci; that his business

contained in envelopes 26, 37 and 67 is meagre and adds no information of particular importance, we have decided to describe only the documentation produced in 1932 (Section 15). No documentation for the years 1934-1935 has been found in this category.

${ }^{43}$ Copies of the report sent by Stokes to Guido Leto and of the already mentioned report based on British sources are in fact also to be found in the Central State Archive, Ministry of Internal Affairs, Police Directorate General, General and Classified Affairs Division, permanent categories, G1 (associations) 1912-1945, Envelopes 272 and 288, fasc. 293 (general affairs and England). The envelope we are considering also contains a note dated 6 June 1931 on which it is annotated that it had been sent by Sig. Dansey (documents on a person called Cyril Maurice Dansey, born in 1910, are kept in London at the National Archives and marked as intelligence, but they only cover the years 1939-1946). 
relations with the well-known Dr. Tumminelli (and not Tummicelli) concerned the publication of a study by Chens [sic!] on monetary reform, translated by Sraffa and published by Treves, the Milan publishing house. ${ }^{44}$ Sraffa's father, Prof. Angelo, was dean of the University of Milan and first head of the University of Milan faculty of law, and had been appointed by the fascist government as Grand Officer of the Order of the Crown of Italy. Prof. Angelo Sraffa is on excellent terms with Senator Gentile and various other personages of the regime. ${ }^{45}$

The order to detain Sraffa was, however, withdrawn on 27 September 1931, when the Ministry of Internal Affairs - possibly also subsequent to the assessment of the situation by the Embassy to London mentioned above - sent to the Prefecture of the Kingdom and the Police Department of Rome the message to change the detention order into report and surveillance. It is, however, of some significance that in 1931 Sraffa had actually returned to Italy twice, on 30 June and 24 September - without being stopped on the border, as outlined in a classified note sent by the Directorate General of the Police from the Prefecture of Turin on 26 November 1931. It reported that «Prof. Sraffa, who appears to have entered the Kingdom by the Bardonecchia pass on 30 June last, could not have been subjected to any police procedure, nor even reported, since his name appeared in the Ministerial Register (Rubrica Ministeriale) only in the supplement of 1 July, which arrived in the Bardonecchia police office sometime around the $10^{\text {th }}$ or $15^{\text {th }}$ of the month. Effectively, Sraffa entered the Kingdom on 24 September last by the Grande Moncenisio pass on his way to Genoa. He bore a passport [...]. As already reported with prefecture note n. 021369 of 13 of this month, on entering the Kingdom Sraffa was not detained due to a misinterpretation by the Susa Police Office of the ministerial circular n. 34636 of 29.9.1929». According to the report dated 7 October 1931 referring to the Ministerial Communication of 27 September mentioned above, Sraffa left Italy for England on 5 October by the Como San Giovanni railway pass.

\section{Archivio Centrale dello Stato}

Ministero dell'Interno, Direzione generale di Pubblica sicurezza, Divisione affari generali e riservati, categorie annuali, 1932 - sezione $I^{\mathrm{a}}$, K1B (Partito comunista all'estero), busta 35, fascicolo Inghilterra.

Documents produced in the period January - June 1932.

The documentation regarding Sraffa consists mainly of reports made by the various prefectures on his return to Italy on 24 March, on the occasion of the Easter holidays,

\footnotetext{
${ }^{44}$ J.M. Keynes, La riforma monetaria, translation by Piero Sraffa, Milano, F.lli Treves, 1925.

${ }^{45}$ Of course, in 1931 Sraffa was not a student and Angelo Sraffa had been head of the Faculty of Law at the (State) University of Milan, but not Dean of that University; he had in fact been Dean of the Università Commerciale Luigi Bocconi.
} 
and the surveillance made of his movements within Italian territory (a stay in Rome from 1 to 3 April, departure from Rapallo for Paris on 6 April 1932).

The first document present, sent by the Under Secretary of State at the Ministry of Foreign Affairs (Amedeo Fani) to the Police Directorate General, is dated 19 January 1932; it casts light on certain aspects of the failure to detain Sraffa on 24 September 1931:

In making it known that it has informed the above-mentioned of the acceptance of the resignation submitted by full professor of political economy at the University of Cagliari, the Embassy to London reports that the person in question is at present in Nice, and will be returning to Cambridge at some time in the first half of this month.

In the course of a private conversation held before his departure with an official of the above-mentioned Embassy, Sraffa stated that on his last stay in Italy, he and his luggage had been subjected to lengthy and meticulous search at the frontier, apparently Chiasso, and that on that occasion he had had the opportunity to be able to read in the book or on the page left open before him by the frontier officials his name, surname and qualification in the list of persons who were to be stopped on entering the Kingdom. It was, he stated, later explained to him that the fact that he had nevertheless not been stopped was due solely to an error or oversight of the frontier authorities, and that the provision should have been carried out in compliance with a proper and precise opinion expressed by the London Embassy. ${ }^{46}$

The fact is that subsequent to these circumstances Sraffa, who was accustomed to spending his holidays in Italy (he made a point of travelling to the country, also to show that he was not mixed up in antifascist activities and therefore had no need to fear any reprisals or unfavourable measures on our part), has this time decided to forego his travels lest he should be subjected to severe police measures, and has consequently left for Nice.

On this occasion, when asked by the above-mentioned Official whether he had perchance, above all during his brief stays in France, had relations and contact with anti-fascists and refugees, Sraffa stated that such relations were limited solely to some very few chance encounters in the street with Rosselli and others, whom he has known for a long time, and that the short conversations had with them were no more than everyday small talk between acquaintances.

While confirming that he is not a fascist, Sraffa again explicitly stated that he had not engaged in any antifascist activities during the time spent abroad, nor intended to; that he had never been mixed up in propaganda or suspect circles of refugees, and that, in short, he limited all his activities to study and his professional duties.

There is no telling how far Sraffa's assurances can be taken at their face value, but it is necessary to recognise the fact that he is by now professionally settled in Cambridge

\footnotetext{
${ }^{46}$ In a text of 31 December 1931 (previously cited in Section 11), which constitutes the basis upon which the present document was drawn up, it is supposed that Sraffa had obtained this information from a source in the Ministry of Internal Affairs.
} 
and that he has thereby automatically taken on a much greater degree of independence from us then he had formerly enjoyed.

It is to be remembered that the London Embassy made explicit reference to this eventuality, which has occurred today, in a report of August 1931 and also in n.317608/7627 of 19 September, and in which the Ministry expressed an opinion against stopping and searching Sraffa.

This measure, even though implemented only in the form of simple searching, has, however, as a result of the fact that the person in question has come to know of it, had much the same effects that complete implementation would have led to.

It is, in any case, clear that subsequent to his resignation Sraffa ceases to have those particular duties which his role as professor of a University of the Kingdom entailed for him. As things stand, we will have to contemplate prolonged presence of Sraffa in a university centre such as Cambridge, where he has clearly been able to make friends and form acquaintances with influential persons, and where, should he take an openly stated antifascist stance, the result would be headaches that were better avoided as far as possible.

On the other hand, the statements recently made by Sraffa might not be exact or truthful, but it is also possible that they are. This latter possibility could also be borne out by the fact that he does not appear to have engaged in any particular political activities during the by now somewhat prolonged period of time he has spent in the United Kingdom, as the London Embassy has already had occasion to report from time to time. It would therefore be undesirable for the impression received on crossing the Italian border, together with the fact that he remains in doubt as to whether severe police measures await him in Italy, eventually to make of him, out of spite or fear, what so far he does not appear to have become, namely a refugee like Pettoello or Crespi. These latter two personages, firmly based as they are in highly delicate study centres, have for years been engaging in propaganda which it is better not to reinforce with new, young elements, but rather to seek increasingly and more effectively to limit and repress.

Given the above, and given that, as pointed out, we must expect Sraffa to be spending a long time in the United Kingdom, and in view of the fact that the charges brought against him, unless further ascertainments prove the contrary, cannot yet be considered conclusive and decisive, it would be advisable for the Ministry to consider the expediency of letting the person in question know that he can return to Italy and stay there freely, with no fears, as long as his conduct is such as to allow for it. Thus, it would be possible to keep more careful watch over Sraffa as long as he remains in the United Kingdom, and base any future decisions upon sounder evidence; to convince him of the expediency of continuing to refrain from any political activity; and, finally, to prevent a turbulent and all too active centre for anti-fascists and refugees from forming in Cambridge, too.

If the Ministry will kindly make its opinion on the matter known, it will be received with gratitude. 
The Police Directorate answered this letter on the following 4 February, confirming that it had been Sraffa's previous political positions, «in particular in connection with proof of his relations with the well-known communist member of parliament Antonio Gramsci, at present detained», that lay behind the measure to detain him, although it was subsequently modified as a measure of surveillance, also on account of «the news provided by the Ministry».

\section{Archivio centrale dello Stato,}

Presidenza del consiglio dei Ministri, anni 1937-1939, 5.1.5464, Donazione del prof. Piero Sraffa a favore della $R$. Università di Cagliari per la istituzione di una "Fondazione Piero Sraffa" per incremento dell'Istituto Economico giuridico di detta Università.

Documents produced in the period February - October 1938.

The fascicle contains documents regarding Sraffa's intention to donate 60,000 Liras to the University of Cagliari by creating a fund bearing his name. ${ }^{47}$

In order to be able to accept the donation, the Dean sent in formal application to the national Ministry of Education, which in turn applied to the Prime Minister's Office. We then have the exchanges of correspondence between the parties involved, outstanding among which the letter dated 30 July 1938 sent by Bottai, the national Minister of Education, to the Prime Minister's Office in which, having both the Board of Directors and the Academic Senate of the University of Cagliari expressed favourable opinion towards accepting the donation, Sraffa's academic career was briefly outlined and it was stated that «he is not in possession of the necessary requisites in relation to the latest measures» ${ }^{48}$.

Considerable emphasis is also placed on Sraffa's political conduct, citing as reference both the police reports of 1931 and the record of the interrogation subsequent to his visit to Gramsci, in Formia, in the early days of January 1935.

On 8 August 1938 a note regarding Sraffa's donation and another donation made in 1917 by Michele Sacerdoti in favour of the Bar Association of Modena to honour the memory of his son Vittorio, together with the relevant documentation, was sent to Mussolini. Below is part of the text:

\footnotetext{
${ }^{47}$ Such was the sum of the salaries for his Political Economy teaching which Sraffa had not collected since he moved to England and which, already in 1929, he had donated to the University of Cagliari. It hardly seems likely that, ever averse as he was to any publicity attached to his name, Sraffa would have meant to transform the donation into creation of a fund bearing his name. On the contrary, in a letter written in 1949 Sraffa states that, in 1938, his name had been mentioned against his will (Sraffa Papers B16/1/104-5). For a more detailed reconstruction of this episode, see https://sites.google.com/a/uniroma1.it/nerio-naldimateriali-di-ricerca/.

${ }^{48}$ Reference is clearly to the measures on race, which were subsequently combined in the Royal Decree Law of 17 November 1938, n. 1728.
} 


\section{NOTE FOR THE DUCE}

The National Ministry of Education has made the following points:

- The Dean of the University of Cagliari has applied for authorisation to accept the donation of 60,000 liras arranged in favour of that University by Prof. Piero Sraffa, for the creation of a fund to bear the donor's name, the annual yields of which should be allocated to enhancement of the economic-juridical Institute of the grantee University. $[\ldots]^{49}$

Neither Prof. Sraffa nor Sacerdoti are in possession of the requisites of Italian race. As for the political conduct of Sraffa, he appears to have had relations with various antifascist groups in Paris, as well as engaging in antifascist activities, especially in the period during which he held a course in Political Economy at the University of Cambridge.

The above-mentioned Ministry, before entering upon the relevant provisions, in the form of a royal decree, has asked for appropriate instructions.

On both requests Mussolini wrote in blue pencil, «NO».

News of the rejection of the donation was sent to the Directorate General of Higher Education under the national Ministry of Education on 14 August of the same year.

\footnotetext{
${ }^{49}$ Omitted is the part dealing with the file on Michele Sacerdoti.
} 


\section{References}

Canali, M. (2013), Il Tradimento. Gramsci, Togliatti e la verità negata, Venezia, Marsilio.

Ciuffoletti, Z. (1997), I Rosselli. Epistolario familiare di Carlo, Nello, Amelia Rosselli (1914 - 1937), Milano, Mondadori.

Finoia, M. (1988), L'edizione italiana del Ricardo di Sraffa, Rassegna economica, vol. 52, n. 2, pp. 291-303.

Naldi, N. (1998a), Some notes on Piero Sraffa's biography, 1917 - 1927, Review of Political Economy, vol. 10, n. 4, pp. 493-515.

Naldi, N. (1998b), Dicembre 1922: Piero Sraffa e Benito Mussolini, Rivista Italiana degli Economisti, vol. 3, n. 2, pp. 269-297.

Naldi, N. (2004), Piero Sraffa e gli economisti torinesi: Cabiati, Einaudi, Prato, Loria, Jannaccone, Quaderni di Storia dell'Università di Torino, n. 7, pp. 193-225, 20032004; reprinted in Marchionatti, R. (ed.), La scuola di economia di Torino. Coprotagonisti ed epigoni, Fondazione Luigi Einaudi, Studi, n. 47, pp. 225-60, Olschki, Firenze, 2009.

Naldi, N. (2000), The friendship between Piero Sraffa and Antonio Gramsci in the years 1919-1927, European Journal of the History of Economic Thought, vol. 7, n. 1, pp. 79-114.

Naldi, N. (2005), Piero Sraffa: emigration and scientific activity (1921 - 1945), European Journal of the History of Economic Thought, vol. 12, n. 3, pp. 379-402.

Sraffa, P. (1922), Italian Banking To-day, Manchester Guardian Commercial Recostruction in Europe, n. 11, pp. 675-6.

Sraffa, P. (1925), Sulle relazioni tra costo e quantità prodotta, Annali di economia, vol. 2, n. 1, pp. 277-328; English translation in Pasinetti, L. L. (ed.), Italian economic papers (vol. III), Il Mulino-Oxford University Press, 1998.

Sraffa, P. (1986), Saggi, Bologna, Il Mulino.

Tosatti, G. (2009), Storia del Ministero dell'Interno. Dall'Unità alla regionalizzazione, Bologna, Il Mulino. 


\section{Authors contact information:}

Eleonora Lattanzi

Department of Documental, linguistic-philological and geographical sciences, University of Rome "La Sapienza" and Fondazione Istituto Gramsci

e-mail: eleonora.lattanzi@uniroma1.it

Nerio Naldi

Department of Statistics, University of Rome "La Sapienza"

e-mail: nerio.naldi@uniroma1.it 